УДК 37.013.42:376-056.26

DOI: 10.37026/2520-6427-2020-103-3-85-88
Тетяна КОВБАСЮК,

кандидат педагогічних наук, завідувач кафедри педагогіки, психологіï та корекційної освіти Рівненського ОІППО

Лариса ЯЦЕНЮК, старший викладач кафедри педагогіки, психологї та корекційної освіти Рівненського ОІППО

\title{
СОЦІАЛЬНО-ПЕДАГОГІЧНА ПІДТРИМКА БАТЬКІВ ДІТЕЙ 3 ОСОБЛИВИМИ ОСВІТНІМИ ПОТРЕБАМИ В ЗАКЛАДАХ ОСВІТИ
}

У статті проаналізовано основні труднощі сімей, які виховують дітей з особливостями психофізичного розвитку, зокрема акцентовано увагу на важливості психоемоційного стану батьків. Висвітлено напрями та форми роботи з батьками дітей з особливими освітніми потребами. Розкрито значення співпраці фахівиів команди психолого-педагогічного супроводу дитини з особливими освітніми потребами та ї̈ батьків.

Ключові слова: інклюзивне навчання, діти з особливими освітніми потребами, психологічна підтримка, сочіально-педагогічна підтримка батьків дітей з особливими освітніми потребами, команда психолого-педагогічного супроводу дитини.

В статье проанализированы основнье проблемь семей, воспитьвающих детей с особенностями психофизического развития, в частности акиентировано внимание на важности психоэмоционального состояния родителей. Освещены направления и формы работы с родителями детей с особыми образовательными потребностями. Раскрыто значение сотрудничества спечиалистов команды психолого-педагогического сопровождения ребенка с особыми образовательными потребностями и его родителей.

Ключевые слова: инклюзивное обучение, дети с особыми образовательными потребностями, психологическая поддержка, социально-педагогическая поддержка родителей детей с особыми образовательными потребностями, команда психолого-педагогического сопровождения ребенка.

The family of a child with special needs is a primary socializing institution. It forms the moral qualities of the child, its attitude to people, ideas about the nature of interpersonal relationships. Not all parents are able to accept the child's illness, to respond adequately to emerging problems. Such emotional well-being has a negative impact on the mental wealth of both parents and children, their relationships with others. Exacerbates socio-psychological and personal conflicts. Causes problems in learning and mastering social norms of child behavior.

Inclusive education should promote active involvement of parents to solving problems. Parents should constantly learn to cooperate for creation comfort educational environment for child with special educational needs. It is argued the importance of working with parents on psycho-emotional sphere. Psychological support to parents who have children with physical disabilities aimed at such questions: resolving conflict situations that arise between the subjects of educational process; reduction of emotional discomfort of parents due to the peculiarities of child's development, upgrading psychological and pedagogical culture of parents, maintaining their confidence in the child's abilities; supporting of interpersonal relationships in the family upbringing styles.

Based on the analysis of theory and methodic of social-pedagogical work with families who have children with psychophysical disorders, it has been presented following directions: involvement parents in the correctional and educational process; formation of their beliefs of the importance of family in overcoming difficulties of psychophysical development; formation of parents' accepting with its development process, teaching of parents the psychological techniques of working with child at home. It has been recommended such forms of work with parents: communication and active listening; individual counseling, group forms (open days, questionnaires, parent-teacher interviews, thematic consultations, open classes, watching videos, trainings and group psycho-correction classes).

Key words: inclusive education, children with special educational needs, psychological support, social and pedagogical support of parents with special educational needs children, psychological and pedagogical support of the child team.

Постановка проблеми. Не секрет, що в надзвичайно мінливих умовах сьогодення діти загалом, а найбільше - діти 3 порушеннями психофізичного розвитку, які відрізняються від здорових однолітків як фізично, так і ментально, потребують особливої уваги, підтримки, захисту та допомоги. Дитина з особливими освітніми потребами (далі - ООП) не повинна бути ізольована від суспільства. Її входження в соціум має відбуватися в тих самих вікових межах, що й в інших дітей. У зв'язку з цим батьки дітей з ООП опиняються перед непростим вибором 3 моменту, коли дізнаються про їхні психофізичні особливості 
Що ж робити: тримати вдома, піклуючись лише про здоров'я дитини, щоб вона почувала себе комфортно, не викликала зайвого подиву в оточуючих, не відчувала зневаги в однолітків, чи віддати до спеціального закладу або в середовище до здорових дітей? Такі думки постійно хвилюють батьків «особливих дітей», адже саме їм потрібно приймати нелегке рішення. Зважаючи на це, сім'я, в якій виховується дитина $з$ особливостями психофізичного розвитку, потребує особливої уваги.

На сучасному етапі однією із форм здобуття освіти дітьми з особливостями психофізичного розвитку $\epsilon$ інклюзивне навчання, яке передбачає перебування дитини з особливими освітніми потребами у масовому закладі дошкільної чи загальної середньої освіти, оволодіння нею знаннями, вміннями та навичками разом зі здоровими дітьми.

Визначення оптимальних шляхів і засобів упровадження інклюзивної освіти грунтується на засадах відповідного нормативно-правового, методичного, кадрового, матеріально-технічного та психолого-педагогічного забезпечення організації освітнього процесу дітей з особливими освітніми потребами.

Аналіз наукових досліджень і публікацій. Проблемами щодо впровадження інклюзії, залучення дітей з особливими освітніми потребами до навчання в заклади освіти, їх реабілітації та соціалізації займаються вітчизняні науковці, зокрема В. Бондар, А. Колупаєва, Т. Свтухова, В. Ляшенко, І. Іванова, О. Столяренко, Ю. Найда, О. Василенко та ін.

Питання роботи з батьками дітей з особливими освітніми потребами знайшли своє відображення у працях таких дослідників, як Р. Кравченко, М. Радченко, К. Островська, В. Каган, Т. Сак, Т. Скрипник. Вивченню сімей, в яких виховується дитина 3 особливостями психофізичного розвитку як об'єкт соціально-педагогічної допомоги, присвячено розвідки I. Мамайчук, Р. Кравченко, В. Тарасун, В. Мартинова, Д. Шульженко, О. Мастюкової, К. Островської та ін.

Однак, незважаючи на чималу кількість наукових розвідок з інклюзивної та спеціальної освіти, питання ефективної організації соціально-педагогічного супроводу родин, які виховують дітей з особливими освітніми потребами, вимагає подальшого вивчення.

Мета статті - висвітлити основні напрями соціально-педагогічної підтримки батьків дітей з особливими освітніми потребами; проаналізувати принципи роботи з батьками; розкрити основні засади партнерства родини та команди психолого-педагогічного супроводу дитини з ООП.

Виклад основного матеріалу. Сучасний стан розвитку спеціальної педагогіки та психології характеризується пошуком нових шляхів соціальної адаптації дітей з особливостями психофізичного розвитку. Значних успіхів у соціалізації та розвитку такої дитини можна досягнути лише за умови активної участі в цьому процесі сім'ї, передусім - батьків [5].

Успішність інклюзивного навчання значною мірою залежить від рівня адаптації батьків до життєвих умов, пов'язаних із вихованням дитини з особливими освітніми потребами. Якщо в родині панує позитивна атмосфера, доброзичливість, батьки адекватно сприймають особливості своєї дитини, оптимістично налаштовані на іï майбутні успіхи, намагаються розвивати іiї потенціал, постійно шукають нові шляхи, методи, прийоми, засоби навчання та виховання, вони вселяють дитині впевненість у ії силах і можливостях, сприяють іiі фізичному та психічному розвитку.

Утім практика свідчить, що проблема виховання і розвитку «особливої» дитини стає складною для сім'ї, зокрема батьки потрапляють у психологічно непросту ситуацію, відчуваючи біль, горе, провину, часто впадають у відчай.

Узагальнений психологічний портрет батьків дітей 3 інвалідністю характеризується вираженою стурбованістю, високим рівнем тривожності, слабкістю, соціальною боязкістю, підозрілістю. Із власної ініціативи батьки рідко контактують із незнайомими людьми, виявляють своє насторожене ставлення до всіх, хто намагається спілкуватися з їхніми дітьми. Жалість чи подив оточуючих, які побачили їхню хвору дитину, призводить до того, що такі батьки починають ховати дитину від сторонніх очей, намагаються менше бувати з нею в громадських місцях, чим ще більше сприяють іiї соціальній дезадаптації [1]. Подібне емоційне самопочуття негативно впливає на душевне благополуччя як батьків, так і їхніх дітей, а ще - на їхні стосунки з оточуючими, підсилює соціально-психологічні та особистісні конфлікти, спричиняє серйозні проблеми у навчанні та засвоєнні соціальних норм поведінки дитини. Це ускладнює процес соціалізації та інтеграції дитини.

Саме тому інклюзивна освіта покликана сприяти активному залученню батьків до вирішення означених проблем, сприяти тому, щоб вони постійно навчалися співробітництву задля максимально комфортного освітнього процесу дитини з особливими освітніми потребами.

Сьогодні педагоги мають бути підготовлені до роботи 3 усіма членами родини, а батьки - до співпраці із закладом освіти. Досвід показує, що батьки зацікавлені освітою своїх дітей та беруть у ній безпосередню участь, якщо відчувають, що будуть корисні для своєї дитини та усвідомлюють, що заклад освіти спонукає їх до співпраці. Саме ці фактори є важливими для усвідомлення батьками їхньої ролі та власної затребуваності для подальшого комфортного життя їхніх дітей.

Таким чином, інклюзивний підхід покликаний не лише забезпечити навчання, виховання й успішну соціалізацію дітей з особливими освітніми потребами, а й сформувати педагогічно толерантну свідомість у педагогів, батьків дітей із нормотиповим розвитком, а також надати підтримку таким батькам.

Означена психологічна підтримка передусім спрямована на:

- вирішення конфліктних ситуацій, що виникають між суб' єктами освітнього процесу;

- зниження в батьків емоційного дискомфорту у зв'язку з особливостями розвитку їхньої дитини;

- підвищення психолого-педагогічної культури батьків;

- підтримку впевненості батьків у можливостях їхньої дитини;

- допомогу у створенні батьківських об'єднань та участь батьків у їхній діяльності; 
- формування в батьків адекватного ставлення до проблем дитини;

- підтримку міжособистісних стосунків у сім'ї та стилів сімейного виховання.

Останнім часом усе більше батьків дітей з особливими освітніми потребами виявляють бажання, аби їхні діти навчалися та виховувалися разом зі здоровими однолітками. Зрозуміло, що така дитина може відчувати у період інтеграції певні труднощі, однак для неї це буде досвідом, яким вона зможе скористатися у майбутньому.

Із метою забезпечення ефективності освітнього процесу дітей з ООП, які здобувають освіту в умовах інклюзивного навчання в закладах дошкільної чи загальної середньої освіти, створюється команда психолого-педагогічного супроводу. Важливою складовою такої команди є батьки. Вони беруть безпосередню участь в ухваленні рішень, впливають на освітній і загальний розвиток дитини. Як учасники освітнього процесу батьки мають право:

- надавати свій дозвіл на проведення комплексного оцінювання розвитку дитини в інклюзивно-ресурсному центрі;

- мати повну інформацію про умови навчання дитини;

- надавати необхідну інформацію, що може вплинути на навчання і поведінку дитини в закладі освіти;

- брати участь у розробленні індивідуальної програми розвитку (далі - IПР) - документі, що забезпечує індивідуалізацію навчання особи з особливими освітніми потребами, закріплює перелік відповідних психолого-педагогічних, корекційних потреб / послуг для розвитку дитини;

- отримувати від учителів та інших спеціалістів інформацію про розвиток, навчання й успішність дитини, зокрема про реалізацію IПР;

- мати доступ до інформації про навчання дитини в закладі освіти, включаючи результати оцінювання та звіти;

- отримувати консультації фахівців, які працюють із дитиною;

- отримувати звіти про успіхи дитини впродовж навчального року;

- надавати дозвіл на додаткові послуги, що їх може потребувати дитина;

- оскаржувати рішення, які, на думку батьків, не задовольнятимуть особливі освітні потреби дитини, та працювати 3 командою психолого-педагогічного супроводу, шукаючи кращих рішень [3, с. 123].

Соціально-педагогічну підтримку батьків дітей 3 особливими освітніми потребами розглядаємо як комплекс заходів, що забезпечують реалізацію прав дитини, функціональну спроможність сім’ї як соціального інституту виховання, створюють можливість оптимізації процесу взаємодії педагогічного колективу з батьками дітей з особливостями психофізичного розвитку через надання їм необхідної соціальної, педагогічної, психологічної, медичної та іншої допомоги, а також залучення до команди фахівців.

Процес реалізації соціально-педагогічної підтримки батьків тривалий і потребує комплексного підходу. Успішність розвитку дитини з особливими освітніми потребами безпосередньо залежить від порозуміння між членами команди та зосередження на загальній меті.

На практиці фахівцям і батькам буває непросто дійти згоди та працювати злагоджено. Успішна співпраця між фахівцями команди психолого-педагогічного супроводу дитини та батьками відбуватиметься, якщо:

1. Батьки та члени родини приймають дитину, іï діагноз та мають бачення щодо розвитку дитини.

2. Фахівці команди психолого-педагогічного супроводу проводять психодіагностичне обстеження дитини з ООП та надають кваліфіковане роз'яснення його результатів батькам.

3. Батьки дитини довіряють даним обстеження іiі розвитку.

4. Команда супроводу дитини з ООП визначає напрями психолого-педагогічних та корекційно-розвиткових послуг, що можуть бути надані дитині в межах закладу освіти. Зокрема, відповідно до висновку інклюзивно-ресурсного центру, індивідуальної програми реабілітації дитини з інвалідністю (за наявності), результатів психолого-педагогічного вивчення дитини складає індивідуальну програму розвитку дитини з ООП упродовж двох тижнів із моменту початку освітнього процесу. Означену програму погоджують батьки та затверджує керівник закладу освіти [2].

5. Усі фахівці команди психолого-педагогічного супроводу дитини чітко дотримуються своїх обов'язків та несуть відповідальність за спільну діяльність згідно з визначеним планом.

6. У закладі освіти створені належні умови для інтеграції дітей з ООП в освітнє середовище. Проводиться консультативна та інформаційно-просвітницька робота з батьками щодо особливостей розвитку дітей, їхнього навчання та виховання. Надається методична підтримка педагогічним працівникам закладу освіти з організації інклюзивного навчання.

7. Команда супроводу переглядає IПР із метою іiі коригування та визначення прогресу розвитку дитини у закладі загальної середньої освіти двічі на навчальний рік (у разі потреби - частіше), а в закладі дошкільної освіти - тричі на навчальний рік (у разі потреби - частіше) [2].

Основною метою роботи з сім'ями, які виховують дітей з особливостями психофізичного розвитку, $\epsilon$ надання батькам кваліфікованої допомоги. Співпраця 3 батьками допомагає вирішити такі важливі завдання: допомогти сформувати адекватні взаємостосунки між батьками та іншими членами сім'ї; допомогти дорослим створити комфортну сімейну атмосферу; розширити поінформованість батьків щодо потенційних можливостей дитини, іії перспективи у різних аспектах життя; створити умови для активної участі батьків у вихованні та навчанні дитини; навчити батьків прийомам організації навчальної діяльності дитини, підвищити рівень психічного здоров'я самих батьків [5].

Чимало авторів у своїх дослідженнях виділяють такі напрями роботи з сім'ями дітей з особливими освітнім потребами: залучення батьків до корекційно-освітнього процесу, зокрема переконання, що їхня дитина потребує спеціальної допомоги, додаткової уваги, 
особливого підходу; формування віри, що лише за допомогою родини вона зможе подолати труднощі у психофізичному розвитку; формування задоволеності батьків процесом розвитку дитини через демонстрацію досягнень та успіхів (навіть найменших!) у розвитку дитини; розкриття перед батьками творчих підходів до навчання та виховання дитини; навчання батьків психологічним прийомам роботи 3 дитиною вдома. Форми та зміст роботи з батьками визначаються диференційовано, передусім - залежно від ступеня готовності батьків до співпраці.

Рекомендуємо такі форми роботи з батьками дітей, які потребують психофізичної корекції:

Спілкування та активне слухання. Важливим $є$ створення можливостей для різних видів спілкування і взаємодії між педагогічними працівниками, фахівцями та батьками. Спілкування може відбуватися як в усній формі, під час зустрічей із батьками в закладі освіти, відвідування сім'ї вдома, так і в письмовій - за допомогою записок, використання дошки оголошень для інформування батьків із різноманітних питань, зокрема про служби та організації, що надають допомогу й підтримку родинам, які виховують дітей з ООП. Педагогічні працівники повинні вміти вислуховувати батьків, давати можливість ставити запитання, що стосуються психофізичного розвитку їхніх дітей.

Індивідуальне консультування проводиться не частіше одного разу на тиждень на прохання батьків або за ініціативи фахівців. Під час консультацій доцільно: обговорювати результати психолого-педагогічного обстеження дитини й особливості іiі розвитку, демонструючи при цьому прийоми корекційної роботи; інформувати батьків про успіхи дитини; порушувати питання, на які необхідно звернути увагу.

Групові форми роботи з батьками: дні відкритих дверей, анкетування, батьківські збори, тематичні консультації, відкриті заняття, спільний перегляд відеоматеріалів із певної теми, тренінги (як для всіх членів родини, так і окремо для матерів, які самі виховують дитину з ООП), групові психокорекційні заняття. На спеціальних соціально-психологічних тренінгах батьки вчаться сприймати дитину 3 особливостями психофізичного розвитку такою, якою вона є; підтримувати і заохочувати пї до пізнання нового, до дії через гру; надавати дитині можливість вибору (в іграх, одязі, харчуванні); не піддаватися примхам і вимогам дитини; ставити вимоги відповідно до можливостей дитини. У групових дискусіях завжди виробляються нові варіанти ставлення до дитини з ООП, більш продуктивні способи взаємодії 3 нею.

Заслуговує на увагу й така цікава форма роботи, як батьківський всеобуч «Школа життевої компетентності», яку пропонує С. Прокопчук [4]. Вона передбачає інтерактивні форми роботи з батьками дітей шкільного віку. Серед найважливіших завдань «Школи життєвої компетентності» варто виокремити такі: підтримка та розвиток традицій родинного виховання, спрямованих на зміцнення сім'ї; обговорення концептуальних засад сімейно-родинного виховання та проблем виховання дітей; надання допомоги батькам, які не справляються із вихованням дітей з ООП; допомога батькам у переході від позиції вболівань до позиції творчого пошуку; реалізація можливостей дитини з особливостями розвитку; корекція внутрішнього стану батьків; спільна реалізація можливостей життєзабезпечення та виховання дітей з особливими потребами, їхнє лікування та оздоровлення, набуття освіти та спеціальності; переорієнтація батьків із позиції очікування дива на позицію діяльності [4].

Висновки. Добробут дитини залежить від того, наскільки щасливою $є$ родина, в якій вона виховується. Це передусім мають зрозуміти батьки. Невпевненість батьків і неприйняття діагнозу дитини лише загострюють взаємини в сім'ї, негативно впливають на дитину та перешкоджають її розвитку. Повноцінне життя родини, в якій батьки турбуються про саморозвиток, мають власні інтереси, спілкуються з друзями, забезпечує дитині такі умови, за яких ії фізіологічні, емоційні та інтелектуальні потреби реалізуються повною мірою. Як наслідок - у дитини актуалізується потенціал власного життєтворення, допомагає не стояти на місці, а постійно рухатися вперед, розвиваючи свої здібності, компенсуючи недоліки в розвитку й досягаючи успіху.

Отже, завдання фахівців закладу освіти з інклюзивним навчанням - забезпечити дитині всесторонню підтримку, допомогти батькам усвідомити, що вони не самі на шляху подолання труднощів своїх дітей, а батьків - приймати підтримку та сприяти партнерству.

\section{СПИСОК ВИКОРИСТАНОЇ ЛІТЕРАТУРИ}

1. Буковська О. О. Напрямки психологічної допомоги сім'ям, які виховують дитину з особливими потребами. Вісник Чернігівського національного педагогічного університету. Серія «Психологічні науки». 2013. Вип. 114. С. 12-16. URL: file://C:/Users/Admin/ Downloads/VchdpuPH_2013_114_5\%20(3).pdf (дата звернення: 03.07.2020).

2. Про затвердження Примірного положення про команду психолого-педагогічного супроводу дитини $з$ особливими освітніми потребами в закладі загальної середньої та дошкільної освіти : Наказ МОН України від 08.06.2018 р. № 609. URL: https://zakon. rada.gov.ua/rada/show/v0609729-18\#Text (дата звернення: 08.07.2020).

3. Порошенко М. А. Інклюзивна освіта : навчальний посібник / Київ : ТОВ «Агентство «Україна», 2019. C. 123. URL: https://mon.gov.ua/storage/app/ media/inkluzyvne-navchannya/posibniki/inklyuziyavnz. pdf (дата звернення: 06.07.2020).

4. Прокопчук С. М. «Школа життєвої компетентності» для батьків дітей з особливими потребами. URL: http://navigator.rv.ua/index.php? option=com content\&task (дата звернення: 06.07.2020).

5. Роль сім'ї у вихованні дітей 3 особливими потребами. URL: https://sites.google.com/site/ inkluzivnenavcannavukraieni/home/1-1 - processtanovlenna-inkluziie-ta-inkluzivnogo-navcanna/osnoviinkluzivnoie-osviti/rol-sim-ie-u-vihovanni-ditej-zosoblivimi-potrebami (дата звернення 03.07.2020).

Дата надходження до редакиії: 17.06.2020 p. 